\section{Irrigation Method and Fertilizer Concentration Differentially Alter Growth of Vegetable Transplants}

\author{
Jinrong Liu ${ }^{1}$, W. Roland Leatherwood ${ }^{2}$, and Neil S. Mattson ${ }^{2,3}$
}

ADDITIONAL INDEX wORDs. collards, ebb and flow, electrical conductivity, flowering kale, hand watering, lettuce, pepper, subirrigation, tomato

SUMMARY. In the United States, overhead irrigation is common to apply water and dissolved nutrients to vegetable transplants during greenhouse production. Overhead irrigation allows for the control of salt accumulation in the growing medium because excess water can leach salts out of the container. Alternatively, subirrigation saves labor and improves water use efficiency, but soluble salts can accumulate in the upper profile of the containers. Consequently different sets of fertilizer and electrical conductivity (EC) guidelines are required for overhead and subirrigation systems. The objective of this project was to determine the influence of fertilizer concentration and irrigation method (subirrigation vs. overhead irrigation) on the growth of several vegetable transplant crops intended for retail sale. Seedlings of collards (Brassica olevacea var. acephala 'Vates'), kale (B. olevacea var. acephala 'Nagoya Mix'), lettuce (Lactuca sativa 'Buttercrunch'), pepper (Capsicum annuum 'Sweet Banana'), and tomato (Solanum lycopersicum 'Sweet 100') were transplanted into 4-inch-diameter containers and grown in a greenhouse for 4 weeks. Irrigation was provided via ebb and flow benches (subirrigation) or hand-watering (overhead irrigation). Plants received a complete fertilizer solution provided at a concentration of $50,100,200,350$, and $500 \mathrm{mg} \cdot \mathrm{L}^{-1}$ nitrogen $(\mathrm{N})$. The treatments resulting in maximum shoot dry weight (DW) for overhead irrigated plants were $100 \mathrm{mg} \cdot \mathrm{L}^{-1} \mathrm{~N}$ for pepper, $200 \mathrm{mg} \cdot \mathrm{L}^{-1} \mathrm{~N}$ for tomato, and $350 \mathrm{mg} \cdot \mathrm{L}^{-1} \mathrm{~N}$ for collards, kale, and lettuce. Irrigation method and fertilizer treatment significantly affected fresh weight (FW) and DW for kale, lettuce, and pepper. For kale and lettuce, regression analysis indicated that maximum DW was reached at a lower fertilizer concentration with overhead irrigation than subirrigation. The treatments resulting in maximum DW for subirrigated plants were $200 \mathrm{mg} \cdot \mathrm{L}^{-1} \mathrm{~N}$ for kale, lettuce, pepper, and tomato and $350 \mathrm{mg} \cdot \mathrm{L}^{-1} \mathrm{~N}$ for collards. Reducing fertilizer concentration was an effective method for controlling plant height for all crops we examined except for 'Sweet Banana' pepper. However, in many cases height control via nutritional limitation comes at substantial expense to other growth parameters. Our results suggest that, in some cases, fertilizer concentration guidelines for overhead irrigation can be reduced when growing vegetable transplants with subirrigation due to reduced leaching of nutrients and greater potential for accumulation of fertilizer salts.

$\mathrm{V}$ egetable transplants for consumer purchase represent an important segment of the U.S. bedding plant industry. In 2008, the wholesale value of this group was $\approx \$ 92$ million for commercial floriculture growers in surveyed states that had $\$ 100,000$ or more in sales across the U.S. [U.S. Department of Agriculture (USDA), 2009]. The 2009 value represents a \$17 million (or 22\%) increase

We thank Wessels' Farms, Inc. for the donation of plant material; J.R. Peters, Inc. for the donation of fertilizer; and Kelly Coulon and Rachel Brinkman for their technical support. Partial project funding was provided from the New England Greenhouse Conference grant program

${ }^{1}$ College of Pastoral Agriculture Science and Technology, Lanzhou University, Lanzhou 730020, China

${ }^{2}$ Department of Horticulture, Cornell University, 134A Plant Science Building, Ithaca, NY 14853

${ }^{3}$ Corresponding author. E-mail: nsm47@cornell.edu. from 2007. Consumers increasingly favor vegetable transplants that are grown in pots rather than flats. The wholesale value of potted vegetables increased by $31 \%$ between 2007 and 2008 , whereas during the same period the value of vegetable transplants produced in flats increased by $14 \%$ (USDA, 2009).
Chemical growth regulators are not allowed in U.S. vegetable transplant production, with the exception of uniconazole (Sumagic; Valent U.S.A., Walnut Creek, CA) which can only be used for certain vegetables species at seedling age (Schnelle and Barrett, 2009). Therefore, it can be challenging to select a fertilizer concentration during production that balances optimal growth while limiting excessive plant growth. A complete fertilizer at $200-250 \mathrm{mg} \cdot \mathrm{L}^{-1} \mathrm{~N}$ is typically recommended for optimal growth of vegetable transplants, though in practice a concentration as low as $100 \mathrm{mg} \cdot \mathrm{L}^{-1}$ $\mathrm{N}$ may be safely used to avoid excessive plant height (Konjoian, 1999). Specifically, increased phosphorus $(\mathrm{P})$ concentration has been reported to increase height of tomato transplants (Nelson et al., 2002; Rideout and Overstreet, 2003). According to Gibson et al. (2007), the recommended fertilizer $\mathrm{N}$ concentration using a balanced fertilizer with constant liquid feed is 100 to $200 \mathrm{mg} \cdot \mathrm{L}^{-1} \mathrm{~N}$ for 'Nagoya Mix' flowering kale, 75 to $100 \mathrm{mg} \cdot \mathrm{L}^{-1}$ $\mathrm{N}$ for pepper, and 50 to $75 \mathrm{mg} \cdot \mathrm{L}^{-1} \mathrm{~N}$ using a low-P fertilizer for tomato.

Overhead irrigation is the most common method growers use to apply water and dissolved fertilizer nutrients to vegetable transplants during greenhouse production. Using overhead irrigation, the grower may apply water in excess of container requirements so that some water and dissolved nutrients can leach out the bottom of the container and reduce the buildup of soluble salts in the container. The leading concerns with overhead irrigation are labor costs and poor nutrient and water use efficiency (Uva et al., 1998).

Subirrigation is an alternative irrigation method whereby the applied irrigation water and dissolved fertilizer nutrients are applied to the bottom of the container through the use of capillary mats, ebb and flow benches,

\begin{tabular}{llll}
\hline $\begin{array}{l}\text { Units } \\
\text { To convert U.S. to SI, } \\
\text { multiply by }\end{array}$ & U.S. unit & SI unit & $\begin{array}{l}\text { To convert SI to U.S., } \\
\text { multiply by }\end{array}$ \\
\hline 3.7854 & gal & $\mathrm{L}$ & 0.2642 \\
2.54 & inch(es) & $\mathrm{cm}$ & 0.3937 \\
25.4 & inch(es) & $\mathrm{mm}$ & 0.0394 \\
16.3871 & inch & $\mathrm{cm}^{3}$ & 0.0610 \\
1 & mmho/cm & $\mathrm{dS} \cdot \mathrm{m}^{-1}$ & 1 \\
28.3495 & $\mathrm{oz}$ & $\mathrm{g}$ & 0.0353 \\
1 & $\mathrm{ppm}$ & $\mathrm{mg} \cdot \mathrm{L}^{-1}$ & 1 \\
10.7639 & $\mathrm{~W} / \mathrm{ft}^{2}$ & $\mathrm{~W} \cdot \mathrm{m}^{-2}$ & 0.0929 \\
$\left({ }^{\circ} \mathrm{F}-32\right) \div 1.8$ & ${ }^{\circ} \mathrm{F}$ & ${ }^{\circ} \mathrm{C}$ & $\left(1.8 \times{ }^{\circ} \mathrm{C}\right)+32$
\end{tabular}


flooded floors, or flood channels. Unlike overhead irrigation, excess applied water is captured and reused in subirrigation systems. Subirrigation offers improved labor, water, and fertilizer efficiency (Uva et al., 1998). Yet, soluble salts can accumulate to excessive concentrations in the upper profile of the container in these systems (Kang et al., 2004). Excessive fertilizer salts can hinder plant growth (Todd and Reed, 1998) or create conditions conducive to proliferation of root-borne pathogens (Gladstone and Moorman, 1989). Periodic top watering leaches excess salts, but multiple leaching cycles must be used (Todd and Reed, 1998). Repeated leaching increases production costs, requires additional irrigation plumbing, and counteracts the labor, water, and fertilizer efficiencies gained from subirrigation. When compared directly with overhead irrigation, subirrigation has been reported to improve (Mak and Yeh, 2001; Pinto et al., 2008), degrade (Cox, 2001), or have no effect (Dole et al., 1994; Kang et al., 2004) on plant growth depending on species. Since nutrient leaching from subirrigated containers is minimal, lower fertilizer inputs may be required and fertilizer guidelines developed for overhead irrigation are not necessarily appropriate for subirrigation (Kang et al., 2004).

In contrast to readily available information for commercial vegetable transplants intended for field production (Cantliffe and Soundy, 2000; Dufault, 1998) which are grown in small volume containers, relatively little information exists describing the effect of fertilizer concentration and irrigation method on the growth characteristics of vegetable transplants grown for retail sale, which are grown in larger volume containers. Bar-Tal et al. (1990) reported that growing plants in $700-\mathrm{cm}^{3}$ cells, rather than $15-\mathrm{cm}^{3}$ cells, significantly enhanced DW, but effects of fertilizer concentration and container volume on growth were not investigated. Reduced soil volume in small containers results in more rapid changes in EC values, whereas for larger containers, EC values would change over a longer period of time, thus container volume will have an impact on fertility management (Biernbaum and Versluys, 1998). The objective of this experiment was to determine the influence of fertilizer concentration and irrigation method (subirrigation vs. overhead irrigation) on the growth of five vegetable transplant crops. It should be noted that in this experiment we investigate a plant production system characteristic of vegetable bedding transplants grown for the retail market and not small plug transplants intended for commercial field vegetable production.

\section{Materials and methods}

Plant material AND growing CONDITIONs. Plug seedlings of 'Vates' collards, 'Nagoya Mix' flowering kale, 'Buttercrunch' lettuce, 'Sweet Banana' pepper, and 'Sweet 100' tomato were obtained from a commercial producer. The lettuce and flowering kale were from 288-cell plug flats, whereas the remaining plants came from 512-cell flats. On 6 May 2008, the seedlings were transplanted into 4 -inch-diameter plastic containers $\left(495 \mathrm{~cm}^{3}\right)$ that were filled with a commercial soilless substrate (Metro-Mix 360; Sun Gro Horticulture, Vancouver, BC, Canada).

Plants were placed in a greenhouse with temperature set points of $20^{\circ} \mathrm{C}$ during the day $(0800-2000 \mathrm{HR})$ and $16{ }^{\circ} \mathrm{C}$ at night $(2000-0800 \mathrm{HR})$. A $50 \%$ shade curtain was set to automatically close whenever an outdoor weather station recorded instantaneous solar radiation of $600 \mathrm{~W} \cdot \mathrm{m}^{2}$ and reopen at $400 \mathrm{~W} \cdot \mathrm{m}^{2}$. Seedlings were irrigated at transplanting with tap water and grown for $2 \mathrm{~d}$ before treatments commenced. Two days after transplanting (DAT) and before treatments began, pour-through root-zone $\mathrm{pH}$ and $\mathrm{EC}$ measurements were taken (Cavins et al., 2000).

Treatments. Plants were separated into two adjoining greenhouse compartments where irrigation water was provided via subirrigation in one house and overhead irrigation in the second (hand-watering). Temperatures across the experimental period were $19.9 \pm 0.12^{\circ} \mathrm{C}($ mean $\pm \mathrm{SE})$ and $19.7 \pm 0.12{ }^{\circ} \mathrm{C}$ in the subirrigation and overhead irrigation greenhouses, respectively. In each greenhouse, one bench was reserved for each fertilizer treatment and plants were irrigated thoroughly daily. Fertilizer concentration treatments were $50,100,200$, 350 , or $500 \mathrm{mg} \cdot \mathrm{L}^{-1} \mathrm{~N}$ from a commercial fertilizer mix that contained $20 \mathrm{~N}-$ 2.2P-16.6K (Jack's Professional LX ${ }^{\mathrm{TM}}$ 21-5-20 All Purpose Water Soluble Fertilizer; J.R. Peter's, Allentown, PA).
Because the tap water was low in magnesium, each fertilizer treatment was also supplemented with $30 \mathrm{mg} \cdot \mathrm{L}^{-1} \mathrm{mag}$ nesium added from magnesium sulfate $\left(\mathrm{MgSO}_{4} \cdot 7 \mathrm{H}_{2} \mathrm{O}\right)$. The municipal tap water had an EC of $0.4 \mathrm{dS} \cdot \mathrm{m}^{-1}$ and alkalinity of $111 \mathrm{mg} \cdot \mathrm{L}^{-1}$ calcium carbonate $\left(\mathrm{CaCO}_{3}\right)$. Fertilizer treatments were mixed in 10-gal stock tanks at 100 times the applied concentration. An injector calibrated to a $1: 100$ ratio and stock solutions were used to fill the 140-gal reservoirs corresponding to each subirrigation treatment. An injector and the treatment stock tanks were also used for the overhead irrigation treatments. Beginning 6 DAT, a weekly $\mathrm{pH}$ and $\mathrm{EC}$ measurement was taken for each fertilizer treatment in the subirrigation (reservoir) and overhead watered (hose end) treatments (Table 1) to verify consistent fertilizer supply over time.

Measurements and statistiCAL ANALYSIS. Beginning at 13 DAT, weekly pour-through root-zone $\mathrm{pH}$ and EC measurements of 10 randomly selected plants (across all crops) from each bench were taken using the method cited above. At 27 DAT plant height was measured as the distance from the medium surface to the tallest part of the plant. At 30 DAT plants were destructively harvested at the medium surface to determine shoot FW and stem diameter. Stem diameter was measured on the main stem with a digital caliper at $1 \mathrm{~cm}$ above the medium surface. Plants were dried in an oven for $3 \mathrm{~d}$ at $70{ }^{\circ} \mathrm{C}$ and shoot DW was recorded.

The experiment was arranged as a completely randomized design with treatments arranged as a split plot with irrigation method as the main plot factor and fertilizer concentration as the subplot factor. There were five replicates per cultivar per fertilizer treatment and two replicates with five repeated measures per species per irrigation treatment. Analysis of variance tests (SAS version 9.1; SAS Institute, Cary, NC) were conducted to identify differences in the measured parameters in response to irrigation or fertilizer treatment. Model testing using contrasts was used to determine the best model, linear or quadratic, to fit the data. Regression analysis was carried out using the regression procedure of SAS (version 9.1). Pairwise comparisons between irrigation treatments were conducted using Tukey's honestly significant difference test at $\alpha=0.05$. 


\section{Results and discussion}

LEACHATE PH AND EC. The baseline leachate $\mathrm{pH}$ (measured 2 DAT, before fertilizer/irrigation treatments) was $6.2 \pm 0.02($ mean \pm SE) and EC was $2.6 \pm 0.17 \mathrm{dS} \cdot \mathrm{m}^{-1}$. For the overhead watering treatment, leachate $\mathrm{pH}$ decreased between 13 and $27 \mathrm{~d}$ (Fig. 1). Final leachate $\mathrm{pH}$ of overhead irrigated plants ranged from 5.3 to 6.3 and was lowest for the 350 and $500 \mathrm{mg} \cdot \mathrm{L}^{-1} \mathrm{~N}$ fertilizer treatments. For the subirrigated plants, leachate $\mathrm{pH}$ decreased slightly between 13 and $27 \mathrm{~d}$ for the 200 to $500 \mathrm{mg} \cdot \mathrm{L}^{-1} \mathrm{~N}$ treatments, but the $\mathrm{pH}$ of the 50 and $100 \mathrm{mg} \cdot \mathrm{L}^{-1} \mathrm{~N}$ treatments increased between 13 and $20 \mathrm{~d}$ and then stabilized for the remaining duration. Final subirrigation leachate $\mathrm{pH}$ was higher than the overhead irrigation leachate $\mathrm{pH}$ ranging from 5.8 to 6.6 , again with the high concentration fertilizer treatments having the lowest substrate $\mathrm{pH}$. Regardless of irrigation method, substrate ECs between 13 and $27 \mathrm{~d}$ were steady or slightly decreased for the 50, 100, and $200 \mathrm{mg} \cdot \mathrm{L}^{-1} \mathrm{~N}$ treatments. However, substrate EC increased between 13 and $27 \mathrm{~d}$ for the 350 and $500 \mathrm{mg} \cdot \mathrm{L}^{-1}$ $\mathrm{N}$ fertilizer treatments, increasing by $\approx 1.5 \mathrm{dS} \cdot \mathrm{m}^{-1}$ in the $500 \mathrm{mg} \cdot \mathrm{L}^{-1} \mathrm{~N}$ treatment. By the end of the experiment, leachate EC was greater in the overhead treatment $\left(5.3 \mathrm{dS} \cdot \mathrm{m}^{-1}\right)$ than the subirrigation treatment (4.7 $\left.\mathrm{dS} \cdot \mathrm{m}^{-1}\right)$. The conventional thought is that subirrigation promotes the accumulation of excess salts in the substrate; this was not indicated by our leachate measurements. However, others report that subirrigated containers accumulate excess salts only in the top-third of the substrate (Kang et al., 2004; Richards and Reed, 2004) due to water evaporation from the substrate surface. Our final pour-through measurements were taken $27 \mathrm{~d}$ after experiment initiation. Both Kang et al. (2004) and Pinto et al. (2008) conducted longterm experiments where pour-through EC measurements of subirrigated plants were compared with overhead watered plants. As in our experiment, these researchers also found that for the first 30-40 d following experiment initiation, measured EC values in the highest fertilizer treatment were greater in overhead watered plants as compared with subirrigated plants. After a longer time period (i.e., across 70-90 d), measured pour-through EC was greater in

Table 1. Electrical conductivity (EC) and $\mathrm{pH}$ of the overhead irrigation and subirrigation solutions used to fertilize vegetable transplants. Data are single measurements taken $6,13,20$, and $27 \mathrm{~d}$ after vegetable seedlings were transplanted. Irrigation and fertilizer treatments began $2 \mathrm{~d}$ after transplanting.

\begin{tabular}{lccc}
\hline $\begin{array}{l}\text { Irrigation } \\
\text { method }\end{array}$ & $\begin{array}{c}\text { Fertilizer concn } \\
\left(\mathbf{m g} \cdot \mathbf{L}^{-1} \text { nitrogen }\right)^{\mathrm{z}}\end{array}$ & $\begin{array}{c}\mathrm{pH} \\
(\text { mean } \pm \mathrm{SE})\end{array}$ & $\begin{array}{c}\mathrm{EC}[\mathrm{mean} \pm \mathrm{SE} \\
\left.\left(\mathbf{d S} \cdot \mathbf{m}^{-\mathbf{1}}\right)\right]^{\mathbf{z}}\end{array}$ \\
\hline Overhead & & & \\
& 50 & $6.6 \pm 0.16$ & $0.85 \pm 0.03$ \\
100 & $6.7 \pm 0.15$ & $1.13 \pm 0.01$ \\
200 & $6.5 \pm 0.10$ & $1.61 \pm 0.03$ \\
350 & $6.4 \pm 0.05$ & $2.32 \pm 0.02$ \\
& 500 & $6.2 \pm 0.09$ & $3.11 \pm 0.05$ \\
Subirrigation & & \\
& 50 & $7.2 \pm 0.19$ & $0.88 \pm 0.03$ \\
& 100 & $7.3 \pm 0.19$ & $1.18 \pm 0.02$ \\
& 200 & $7.0 \pm 0.22$ & $1.79 \pm 0.05$ \\
& 350 & $7.0 \pm 0.23$ & $2.48 \pm 0.07$ \\
& 500 & $6.8 \pm 0.25$ & $3.23 \pm 0.08$ \\
\hline
\end{tabular}

${ }^{2} 1 \mathrm{mg} \cdot \mathrm{L}^{-1}=1 \mathrm{ppm}, 1 \mathrm{dS} \cdot \mathrm{m}^{-1}=1 \mathrm{mmho} / \mathrm{cm}$.
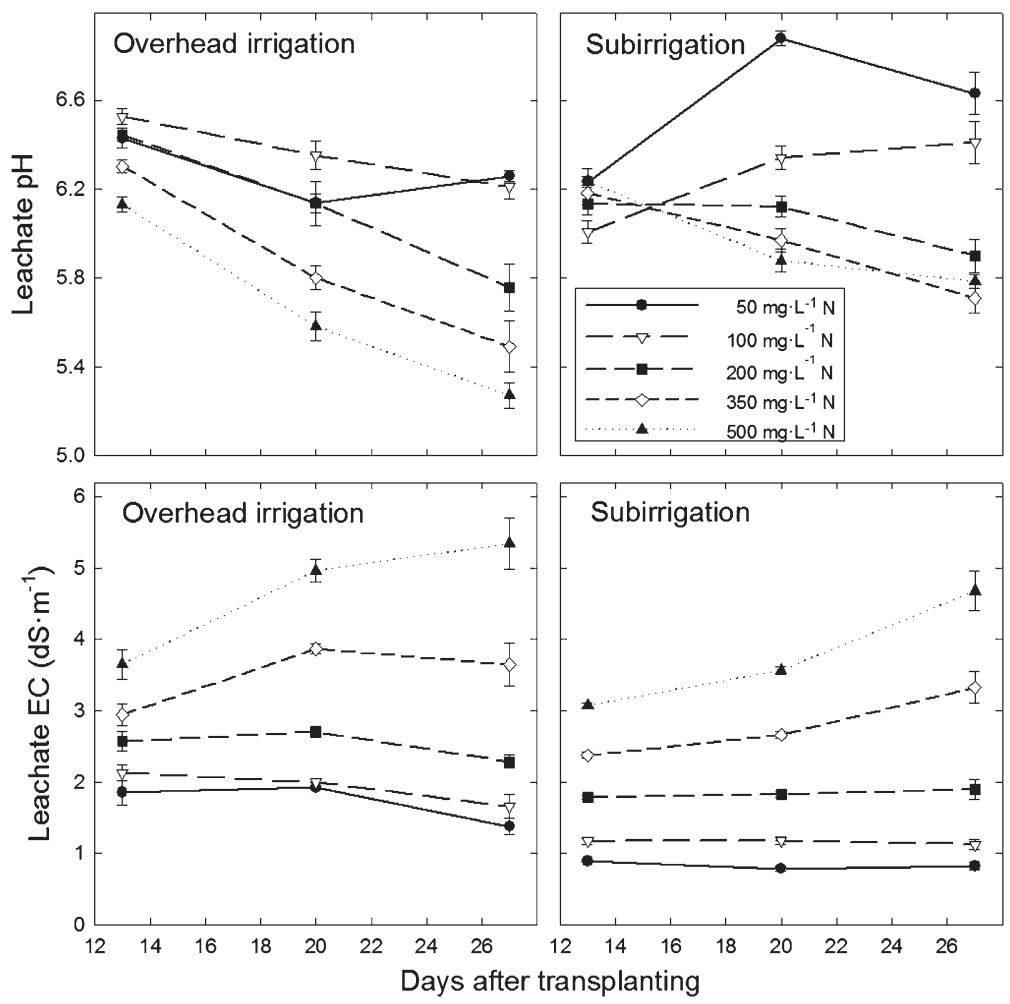

Fig. 1. Leachate $\mathrm{pH}$ and electrical conductivity as determined through pourthrough measurements taken 13,20 , or $27 \mathrm{~d}$ after vegetable seedlings were transplanted. Irrigation and fertilizer treatments began $2 \mathrm{~d}$ after transplanting. Data points are means $( \pm \mathrm{SE})$ of 10 plants on each treatment bench; $1 \mathrm{mg} \cdot \mathrm{L}^{-1}=1$ $\mathrm{ppm}, 1 \mathrm{dS} \cdot \mathrm{m}^{-1}=1 \mathrm{mmho} / \mathrm{cm}$.

subirrigated plants. In general, because salts are accumulated in the upper profile, pour-through leachate measurements may not accurately reflect $\mathrm{pH}$ and EC conditions coinciding with the region of the substrate where roots are actively growing. Therefore, we propose that $1: 2$ dilution method for substrate $\mathrm{pH}$ and $\mathrm{EC}$ analysis may be more appropriate for subirrigated plants.
Collards growth. Dry weight, FW, height, and stem diameter of collards were significantly affected by fertilizer concentration and irrigation method (Table 2). Regression analysis shows that $400 \mathrm{mg} \cdot \mathrm{L}^{-1} \mathrm{~N}$ may be the optimal fertilizer concentration for collards, whereas concentrations greater than $400 \mathrm{mg} \cdot \mathrm{L}^{-1} \mathrm{~N}$ cause a slight decline in FW and DW. Shoot DW with 
Table 2. Two-way analysis of variance for the main effects and interactions of fertilizer concentration [Fert (50, 100, 200, 350 , and $500 \mathrm{mg} \cdot \mathrm{L}^{-1}$ nitrogen $\left.)\right]^{\mathrm{z}}$ and irrigation [ $\operatorname{Irr}$ (overhead irrigation and subirrigation)] on plant dry weight (DW), fresh weight (FW), height, and stem diameter of five vegetable transplant crops. The mean square error (MSE) is presented for the linear and quadratic regression of measured values in response to applied fertilizer rate for overhead (ovr) and subirrigation (sub).

\begin{tabular}{|c|c|c|c|c|c|c|c|c|c|}
\hline \multicolumn{10}{|l|}{ Collards } \\
\hline \multicolumn{2}{|c|}{ Main effects and interactions } & \multicolumn{2}{|c|}{ Plant DW } & \multicolumn{2}{|c|}{ Plant FW } & \multicolumn{2}{|c|}{ Plant ht } & \multicolumn{2}{|c|}{ Stem diam } \\
\hline Source & df & MSE & $P$ value & MSE & $P$ value & MSE & $P$ value & MSE & $P$ value \\
\hline Fert & 4 & 110 & $<0.0001$ & 13973 & $<0.0001$ & 397 & $<0.0001$ & 46 & $<0.0001$ \\
\hline Irr $\times$ Fert & 4 & 3 & 0.1444 & 458 & 0.0068 & 12 & 0.5943 & 1 & 0.2514 \\
\hline \multicolumn{10}{|l|}{ Regression } \\
\hline Linear $_{\text {Sub }}$ & 1 & 62 & $<0.0001$ & 7516 & $<0.0001$ & 147 & $<0.0001$ & 24 & $<0.0001$ \\
\hline Quadratic $_{\text {Sub }}$ & 1 & 8 & 0.0016 & 2036 & $<0.0001$ & 46 & 0.0019 & 2 & 0.0213 \\
\hline
\end{tabular}

Kale

\begin{tabular}{|c|c|c|c|c|c|c|c|c|c|}
\hline \multicolumn{2}{|c|}{ Main effects and interactions } & \multicolumn{2}{|c|}{ Plant DW } & \multicolumn{2}{|c|}{ Plant FW } & \multicolumn{2}{|c|}{ Plant ht } & \multicolumn{2}{|c|}{ Stem diam } \\
\hline Source & $\mathrm{df}$ & MSE & $P$ value & MSE & $P$ value & MSE & $P$ value & MSE & $P$ value \\
\hline Irr & 1 & 37 & $<0.0001$ & 2584 & $<0.0001$ & 303 & $<0.0001$ & 0 & 0.7569 \\
\hline Fert & 4 & 53 & $<0.0001$ & 33075 & $<0.0001$ & 477 & $<0.0001$ & 28 & 0.0001 \\
\hline Irr $\times$ Fert & 4 & 5 & $<0.0001$ & 2266 & 0.0014 & 74 & $<0.0001$ & 1 & 0.4027 \\
\hline \multicolumn{10}{|l|}{ Regression } \\
\hline Linear $_{\text {Ovr }}$ & 1 & 72 & $<0.0001$ & 10674 & $<0.0001$ & 65 & $<0.0001$ & 39 & $<0.0001$ \\
\hline Quadratic $_{\text {Sub }}$ & 1 & 63 & $<0.0001$ & 10407 & $<0.0001$ & 158 & $<0.0001$ & 16 & 0.0007 \\
\hline
\end{tabular}

Lettuce

\begin{tabular}{|c|c|c|c|c|c|c|c|c|c|}
\hline \multicolumn{2}{|c|}{ Main effects and interactions } & \multicolumn{2}{|c|}{ Plant DW } & \multicolumn{2}{|c|}{ Plant FW } & \multicolumn{2}{|c|}{ Plant ht } & \multicolumn{2}{|c|}{ Stem diam } \\
\hline Source & $\mathrm{df}$ & MSE & $P$ value & MSE & $P$ value & MSE & $P$ value & MSE & $P$ value \\
\hline Irr & 1 & 8 & 0.0005 & 7027 & $<0.0001$ & 416 & 0.0003 & 0 & 0.7585 \\
\hline Fert & 4 & 63 & $<0.0001$ & 7675 & $<0.0001$ & 215 & 0.0001 & 14 & 0.0050 \\
\hline Irr $\times$ Fert & 4 & 24 & $<0.0001$ & 1049 & $<0.0001$ & 14 & 0.5793 & 10 & 0.0330 \\
\hline \multicolumn{10}{|l|}{ Regression } \\
\hline Linear $_{\text {Ovr }}$ & 1 & 20 & $<0.0001$ & 4535 & $<0.0001$ & 178 & 0.0075 & 4 & 0.2225 \\
\hline Quadratic $_{\text {Sub }}$ & 1 & 45 & $<0.0001$ & 18994 & $<0.0001$ & 76 & 0.1568 & 81 & $<0.0001$ \\
\hline
\end{tabular}

Pepper

\begin{tabular}{|c|c|c|c|c|c|c|c|c|c|}
\hline \multicolumn{2}{|c|}{ Main effects and interactions } & \multicolumn{2}{|c|}{ Plant DW } & \multicolumn{2}{|c|}{ Plant FW } & \multicolumn{2}{|c|}{ Plant ht } & \multicolumn{2}{|c|}{ Stem diam } \\
\hline Source & $\mathrm{df}$ & MSE & $P$ value & MSE & $P$ value & MSE & $P$ value & MSE & $P$ value \\
\hline Irr & 1 & 17 & $<0.0001$ & 518 & $<0.0001$ & 84 & $<0.0001$ & 2 & 0.0535 \\
\hline Fert & 4 & 2 & $<0.0001$ & 213 & $<0.0001$ & 14 & 0.0332 & 3 & 0.0003 \\
\hline \multicolumn{10}{|l|}{ Regression } \\
\hline Linear $_{\mathrm{Ovr}}$ & 1 & 1 & 0.0073 & 116 & 0.0046 & 18 & 0.0136 & 2 & 0.0355 \\
\hline Quadratic $_{\text {Sub }}$ & 1 & 5 & $<0.0001$ & 600 & $<0.0001$ & 17 & 0.1100 & 3 & 0.0133 \\
\hline
\end{tabular}

Tomato

\begin{tabular}{lcrrrrrrrr}
\hline Main effects and interactions & \multicolumn{4}{c}{ Plant DW } & \multicolumn{2}{c}{ Plant FW } & \multicolumn{2}{c}{ Plant ht } & \multicolumn{2}{c}{ Stem diam } \\
\hline Source & df & MSE & Pvalue & MSE & Pvalue & MSE & $P$ value & MSE & $P$ value \\
Irr & 1 & 141 & $<0.0001$ & 4435 & $<0.0001$ & 1314 & $<0.0001$ & 0 & 0.9934 \\
Fert & 4 & 68 & $<0.0001$ & 8199 & $<0.0001$ & 399 & $<0.0001$ & 6 & $<0.0001$ \\
Irr $\times$ Fert & 4 & 5 & $<0.0001$ & 443 & $<0.0001$ & 32 & 0.0097 & 1 & 0.0299 \\
\hline
\end{tabular}


Table 2. (Continued) Two-way analysis of variance for the main effects and interactions of fertilizer concentration [Fert (50, $100,200,350$, and $500 \mathrm{mg} \cdot \mathrm{L}^{-1}$ nitrogen $\left.)\right]^{\mathrm{z}}$ and irrigation [ $\operatorname{Irr}$ (overhead irrigation and subirrigation)] on plant dry weight (DW), fresh weight (FW), height, and stem diameter of five vegetable transplant crops. The mean square error (MSE) is presented for the linear and quadratic regression of measured values in response to applied fertilizer rate for overhead (ovr) and subirrigation (sub).

\begin{tabular}{|c|c|c|c|c|c|c|c|c|c|}
\hline \multicolumn{10}{|l|}{ Tomato } \\
\hline Main effects and interactions & & \multicolumn{2}{|c|}{ Plant DW } & \multicolumn{2}{|c|}{ Plant FW } & \multicolumn{2}{|c|}{ Plant ht } & \multicolumn{2}{|c|}{ Stem diam } \\
\hline \multicolumn{10}{|l|}{ Regression } \\
\hline Quadratic $_{\mathrm{Ovr}}$ & 1 & 31 & $<0.0001$ & 4117 & $<0.0001$ & 42 & $<0.0001$ & 1 & 0.0114 \\
\hline Linear $_{\text {Sub }}$ & 1 & 112 & $<0.0001$ & 9675 & $<0.0001$ & 369 & $<0.0001$ & 9 & $<0.0001$ \\
\hline Quadratic $_{\text {Sub }}$ & 1 & 66 & $<0.0001$ & 12487 & $<0.0001$ & 141 & 0.0004 & 10 & $<0.0001$ \\
\hline
\end{tabular}

${ }^{\mathrm{z}} \mathrm{l} \mathrm{mg} \cdot \mathrm{L}^{-1}=1 \mathrm{ppm}$.

$350 \mathrm{mg} \cdot \mathrm{L}^{-1} \mathrm{~N}$ was 3.9- and 3.2-fold greater than $50 \mathrm{mg} \cdot \mathrm{L}^{-1} \mathrm{~N}$ plants receiving overhead irrigation or subirrigation, respectively (Fig. 2). Stem diameter increased with increasing fertilizer concentration across the entire fertilizer range (Fig. 2). Stem diameter may be used as an indicator of plant strength (Kang et al., 2004), which is important for shipping and plant establishment. Plant height increased as fertilizer concentration increased from 50 to $200 \mathrm{mg} \cdot \mathrm{L}^{-1} \mathrm{~N}$ and was not significantly different as fertilizer concentration increased to $500 \mathrm{mg} \cdot \mathrm{L}^{-1}$ N. Subirrigated collards exhibited increased growth parameters across all fertilizer concentrations compared with overhead watered plants. There are two possible explanations for this observation. First, the relatively high fertility needs of collards were perhaps more easily satisfied in subirrigation. Second, subirrigation supplies water more uniformly compared with overhead irrigation (Cantliffe and Soundy, 2000), meaning that each plant receives a thorough watering to container capacity during each irrigation event (Pinto et al., 2008); whereas consistent, even application with overhead irrigation can be difficult to achieve. In fact, we found that when averaged across all fertilizer treatments FW/DW of all crops in our experiment was greatest when plants were subirrigated as opposed to overhead watered.

Kale Growth. Fertilizer concentration and irrigation method significantly affected FW, DW, and height of kale (Table 2). Kale reached its highest FW and DW at $350 \mathrm{mg} \cdot \mathrm{L}^{-1}$ $\mathrm{N}$. There was significant interaction between irrigation methods on FW, DW, and stem diameter (Table 2); i.e., regression analysis indicated subirrigated plants reached optimal ( $\mathrm{max}^{-}$ imum) FW with the $300 \mathrm{mg} \cdot \mathrm{L}^{-1} \mathrm{~N}$ treatment, whereas overhead irrigated plants reached optimal FW at 400 mg. $\mathrm{L}^{-1} \mathrm{~N}$ (Fig. 2). The FW and DW of subirrigated kale was sensitive to high fertilizer concentration as both declined at $\mathrm{N}$ concentrations greater than $350 \mathrm{mg} \cdot \mathrm{L}^{-1} \mathrm{~N}$. Overhead irrigated kale DW and FW did not significantly decline at concentrations greater than $350 \mathrm{mg} \cdot \mathrm{L}^{-1} \mathrm{~N}$. The difference in growth patterns in the two treatments suggests that accumulating salts reduced growth in the subirrigation treatment. Although greater accumulated salts in subirrigated plants are not indicated from Fig. 1, the pour-through leachate method may not have accurately accounted for salts levels across the entire substrate volume. When averaged across all fertilizer treatments, the FW, DW, and height of subirrigated plants were generally greater than overhead irrigated plants. There were no significant differences in stem diameter between irrigation methods, yet stem diameter did follow a general quadratic relationship in both irrigation methods.

LeTTUCE GROWTH. There was a significant interaction between irrigation method and fertilizer concentration on the FW and DW of lettuce (Table 2). Subirrigated plants reached their highest DW and FW at 200 $\mathrm{mg} \cdot \mathrm{L}^{-1} \mathrm{~N}$, whereas overhead irrigated plants reached their highest DW and FW at $350 \mathrm{mg} \cdot \mathrm{L}^{-1} \mathrm{~N}$ (Fig. 2). Further, FW and DW of subirrigated plants was reduced by high concentration fertilizer treatments (350 and $500 \mathrm{mg} \cdot \mathrm{L}^{-1} \mathrm{~N}$ ) (Fig. 2). Stem diameter was not significantly affected by irrigation treatment; regarding fertilizer treatment, the only significant reductions are observed at $500 \mathrm{mg} \cdot \mathrm{L}^{-1}$ $\mathrm{N}$ (Fig. 2). Height of overhead irrigated plants was shortest at $50 \mathrm{mg} \cdot \mathrm{L}^{-1}$ $\mathrm{N}$ averaging $19.8 \pm 0.9 \mathrm{~cm}$, greatest at $350 \mathrm{mg} \cdot \mathrm{L}^{-1} \mathrm{~N}$ averaging $34.7 \pm 1.5$ $\mathrm{cm}$, and declined as fertilizer concentration increased to $500 \mathrm{mg} \cdot \mathrm{L}^{-1} \mathrm{~N}$ averaging $24.9 \pm 0.6 \mathrm{~cm}$. Our results are similar to those of Masson et al. (1991) who reported that shoot DW of overhead irrigated 'Ithaca' lettuce grown in a 288-cell plug tray was greatest at $300 \mathrm{mg} \cdot \mathrm{L}^{-1} \mathrm{~N}$ for unlighted plants and $400 \mathrm{mg} \cdot \mathrm{L}^{-1} \mathrm{~N}$ for plants receiving supplemental light. Similarly, Tremblay and Senecal (1988) reported that shoot growth of lettuce seedlings was greater at $350 \mathrm{mg} \cdot \mathrm{L}^{-1} \mathrm{~N}$ as compared with $150 \mathrm{mg} \cdot \mathrm{L}^{-1} \mathrm{~N}$. However, higher $\mathrm{N}$ fertility reduced the root:shoot ratio and was considered not acceptable for high quality vegetable transplants for field production (Tremblay and Senecal, 1988).

Pepper growth. Fresh weight and DW of pepper were significantly affected by fertilizer and irrigation method (Table 2). Subirrigated pepper appeared sensitive to soluble salt accumulation. The greatest pepper FW and DW occurred at $200 \mathrm{mg} \cdot \mathrm{L}^{-1} \mathrm{~N}$ but declined dramatically at $350 \mathrm{mg} \cdot \mathrm{L}^{-1} \mathrm{~N}$ (Fig. 2). The FW of overhead plants was greatest at $100 \mathrm{mg} \cdot \mathrm{L}^{-1} \mathrm{~N}$ and did not vary significantly at higher fertilizer concentrations. Similarly, overhead watered plant DW increased significantly between 50 and $100 \mathrm{mg} \cdot \mathrm{L}^{-1} \mathrm{~N}$ but did not vary significantly at higher fertilizer concentrations.

Height of pepper plants was significantly affected by fertilizer concentration, but these differences were quite small (Table 2). However, pepper height did differ significantly between irrigation treatments at each fertilizer concentration except 50 and $100 \mathrm{mg} \cdot \mathrm{L}^{-1} \mathrm{~N}$. Stem diameter of pepper was largely unaffected by irrigation method. At the end of the study, pepper and tomato plants did not have flowers under any of the 

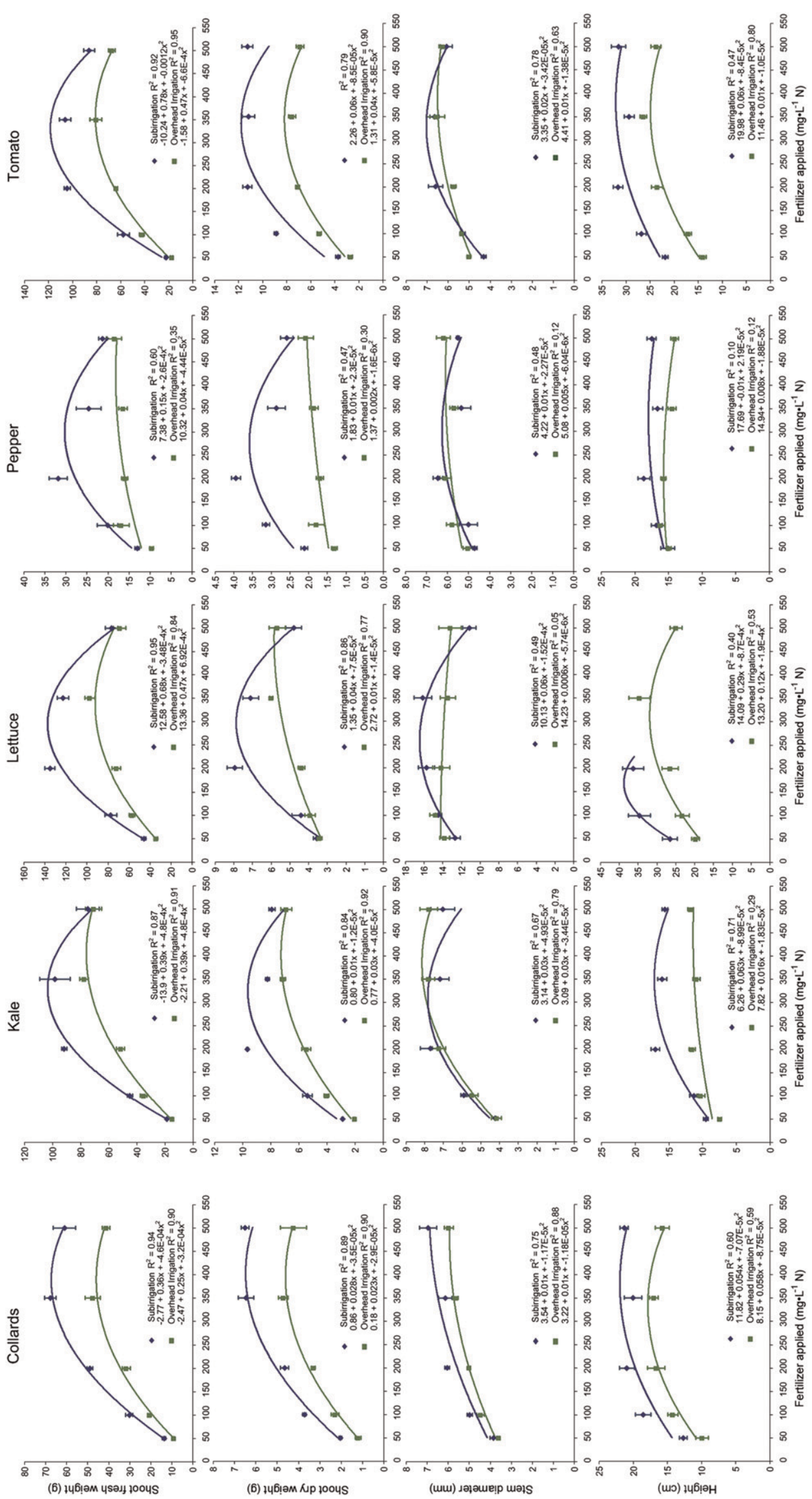

Fig. 2. The effect of applied fertilizer concentration $\left[50,100,200,350\right.$, and $500 \mathrm{mg} \cdot \mathrm{L}^{-1}$ nitrogen $\left.(\mathrm{N})\right]$ and irrigation method (overhead or subirrigation) on measured growth parameters of five vegetable transplant crops. Data points are means $( \pm \mathrm{SE})$ of five plants; $1 \mathrm{mg} \cdot \mathrm{L}^{-1}=1 \mathrm{ppm}, 1 \mathrm{~g}=0.0353 \mathrm{oz}, 1 \mathrm{~mm}=0.0394$ inch, $1 \mathrm{~cm}=0.3937$ inch. 


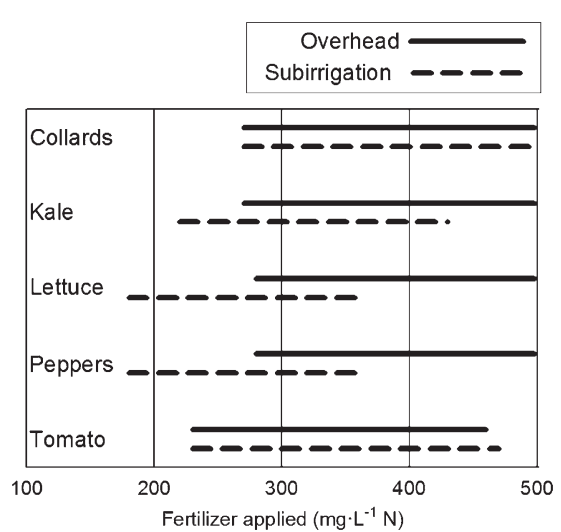

Fig. 3. Optimum fertilizer concentration range for dry weight (DW) of five vegetable transplant crops. Calculated as the fertilizer concentration range that provides $\geq 90 \%$ of optimum DW using the quadratic regression equations presented in Fig. $2 ; 1 \mathrm{mg} \cdot \mathrm{L}^{-1}=1 \mathrm{ppm}$.

treatments; plant fertilizer requirements may change once the plant is in a reproductive stage.

Other researchers have found that the optimal shoot DW and fruit DW of ornamental 'Treasures Red' pepper was reached at $200 \mathrm{mg} \cdot \mathrm{L}^{-1} \mathrm{~N}$ for both subirrigated and overhead irrigated plants (Kang et al., 2004). BarTal et al. (1990) reported the optimal $\mathrm{N}$ and $\mathrm{P}$ concentrations for subirrigated pepper seedlings grown in 15$\mathrm{cm}^{3}$ cells to be $5 \mathrm{~mm} \mathrm{~N}\left(70 \mathrm{mg} \cdot \mathrm{L}^{-1} \mathrm{~N}\right)$ and $0.5 \mathrm{~mm} \mathrm{P}\left(15 \mathrm{mg} \cdot \mathrm{L}^{-1} \mathrm{P}\right)$. Increasing the fertilizer concentration to $10 \mathrm{~mm} \mathrm{~N}$ and $1 \mathrm{~mm} P$ did not increase shoot DW.

Tomato growth. Fresh weight, DW, and height of tomato were significantly affected by fertilizer concentration and irrigation method (Table 2 ). FW of overhead irrigated tomato was $17.6 \pm 0.9 \mathrm{~g} /$ plant at $50 \mathrm{mg} \cdot \mathrm{L}^{-1}$ $\mathrm{N}$ and increased to $80.7 \pm 4.8 \mathrm{~g} /$ plant at $350 \mathrm{mg} \cdot \mathrm{L}^{-1} \mathrm{~N}$ (Fig. 2). For subirrigated plants, the greatest FW was reached at $200 \mathrm{mg} \cdot \mathrm{L}^{-1} \mathrm{~N}$. The $\mathrm{FW}$ under both irrigation regimes decreased at $500 \mathrm{mg} \cdot \mathrm{L}^{-1} \mathrm{~N}$. The DW of both overhead irrigated and subirrigated tomato increased significantly between 50 and $200 \mathrm{mg} \cdot \mathrm{L}^{-1} \mathrm{~N}$ but did not vary significantly at higher fertilizer concentrations. Across all fertilizer concentrations, tomato DW was generally greater under subirrigation mean $9.3 \pm 0.6 \mathrm{~g} /$ plant, compared with overhead irrigated plants mean $5.9 \pm 0.4 \mathrm{~g} /$ plant .

Reduced fertilizer concentration was an effective method of controlling plant height of tomato. The height of overhead plants increased significantly as fertilizer concentration increased from 50 to $350 \mathrm{mg} \cdot \mathrm{L}^{-1} \mathrm{~N}$. However, withholding fertilizer to control height is done so at a direct cost to overall plant growth. The DW of overhead tomato was $7.6 \pm 0.3 \mathrm{~g} /$ plant at 350 $\mathrm{mg} \cdot \mathrm{L}^{-1} \mathrm{~N}$ but was $2.7 \pm 0.2 \mathrm{~g} /$ plant at $50 \mathrm{mg} \cdot \mathrm{L}^{-1} \mathrm{~N}$. Tomato stem diameter was unaffected by irrigation method but tended to follow a quadratic pattern in response to increasing fertilizer concentration. Similarly, Rideout and Overstreet (2003) reported that reducing $\mathrm{P}$ fertilizer concentration from 3.6 to $1.5 \mathrm{mg} \cdot \mathrm{L}^{-1}$ reduced height, DW, and stem diameter of tomato seedlings grown in 128-cell flats. Unlike our experiment, shoot DW of tomato seedlings grown in 128-cell plug trays increased as $\mathrm{N}$ fertilizer concentration increased from 100 to $400 \mathrm{mg} \cdot \mathrm{L}^{-1}$ (Masson et al., 1991).

FERTILIZER RESPONSE AS INFLUENCED BY IRRIGATION METHOD. There was a significant fertilizer concentration by irrigation method interaction for FW and DW of kale, lettuce, and pepper (Table 2). Collards FW exhibited a significant interaction as well, but not DW (Table 2). This relationship indicates a possible gain in fertilizer use efficiency under subirrigation. To further elucidate this relationship, quadratic regression equations were used to determine the fertilizer concentration range that provided $\geq 90 \%$ of optimal DW (Fig. $3)$. Shoot DW was relatively unaffected by irrigation regime for collards and tomato (Fig. 3). However, to reach $90 \%$ of optimal DW of kale, lettuce, and pepper less fertilizer is required under subirrigation, compared with overhead irrigation. For these three crops, deleterious effects were predicted at high fertilizer concentration (greater than 350-440 $\mathrm{mg} \cdot \mathrm{L}^{-1} \mathrm{~N}$ ) under subirrigation, but not with overhead irrigation.

A few reports have directly compared optimal fertilization rates of overhead irrigation and subirrigation, with variable results. The optimal fertilizer concentration for vegetative growth of 'Treasures Red' ornamental pepper was $200 \mathrm{mg} \cdot \mathrm{L}^{-1} \mathrm{~N}$ regardless of irrigation method (Kang et al., 2004). Optimal growth of subirrigated vinca (Catharanthus roseus 'Pacifica Red') was reached at $2 \mathrm{~mm} \mathrm{~K}\left(78 \mathrm{mg} \cdot \mathrm{L}^{-1}\right)$, whereas $4 \mathrm{~mm} \mathrm{~K}\left(156 \mathrm{mg} \cdot \mathrm{L}^{-1}\right)$ was required for top-watered plants (Haley and Reed, 2004). Growth of overhead irrigated poinsettia (Euphorbia pulcherrima 'Gutbier V-14 Glory') was optimal at $250 \mathrm{mg} \cdot \mathrm{L}^{-1} \mathrm{~N}$, whereas a reduced concentration $\left(175 \mathrm{mg} \cdot \mathrm{L}^{-1}\right.$ $\mathrm{N}$ ) was optimal for subirrigated plants (Dole et al., 1994.) However, DW of 'Red Sails' poinsettia was unaffected by fertilizer concentration for both subirrigated and overhead irrigated plants across the range of 100 to $325 \mathrm{mg} \cdot \mathrm{L}^{-1}$ $\mathrm{N}$ (Cox, 2001). Optimal fertilizer concentration for DW of peace lily (Spathiphyllum 'Sensation') was unaffected by irrigation method when plants were grown in a peat-based medium, but plants growing in a coir-based medium had an optimum DW at $8 \mathrm{~mm} \mathrm{~N}$ (112 $\mathrm{mg} \cdot \mathrm{L}^{-1} \mathrm{~N}$ ) for subirrigation and $16 \mathrm{~mm} \mathrm{~N}\left(224 \mathrm{mg} \cdot \mathrm{L}^{-1} \mathrm{~N}\right)$ for top irrigation (Mak and Yeh, 2001).

Besides irrigation method, several production factors are known to influence the fertilizer concentration response of a given plant species, including environmental conditions such as temperature (Kang and van Iersel, 2001) and light intensity (Masson et al., 1991), growth medium (James and van Iersel, 2001; Mak and Yeh, 2001; Poole and Conover, 1992), leaching fraction (Yelanich and Biernbaum, 1993), concentration/proportion of specific nutrients (Haley and Reed, 2004), and salt ions that can accumulate in the root zone (Massa et al., 2009). Taken together, these results suggest that species- and environmentspecific guidelines should be developed for determining whether to decrease fertilizer concentrations when adapting fertilizer guidelines developed for overhead watering to subirrigation systems.

\section{Conclusions}

For vegetable transplants sold primarily for their vegetative characteristics (leaves of collards/lettuce) a profitable production strategy to sell retail vegetable transplants would be to provide a fertilizer treatment that allows a plant to fill the container dimensions (i.e., finish) in the quickest amount of time. Therefore, in our experiment $350 \mathrm{mg} \cdot \mathrm{L}^{-1} \mathrm{~N}$ constant liquid feed would be recommend for collards and $350 \mathrm{mg} \cdot \mathrm{L}^{-1} \mathrm{~N}$ for overhead irrigated and $200 \mathrm{mg} \cdot \mathrm{L}^{-1} \mathrm{~N}$ for subirrigated lettuce. For vegetable transplants that produce fruit (such as pepper and tomato), it is often desirable to retail transplants with flowers or 
fruit on the plant. In this case, the optimal fertilizer practice may not be to produce the largest plant size in the quickest period of time, but rather to maintain the plant at a manageable size while allowing the plant enough time to develop reproductive structures. In this scenario, a fertilizer rate lower than that required for maximum DW gain may be more appropriate. In this study, we did not determine yield performance of transplants once they were planted in the field. A review of commercial vegetable transplant nutrition literature noted that greater root volume and increased fertility during transplant production leads to increased early yield of field-grown vegetables though total yield across the season is often unaffected Dufault (1998). It should be noted the fertilizer rates found in this study to provide optimal plant growth may not be appropriate where small plant size is desired or small volume containers are used such as in production of commercial vegetable transplants/seedlings.

Fertilizer treatments ranging from 50 to $500 \mathrm{mg} \cdot \mathrm{L}^{-1} \mathrm{~N}$ significantly affected growth parameters of all crops examined in this experiment, with a moderate concentration typically optimum for growth. Reducing fertilizer concentration was an effective method for controlling plant height for all crops we examined except 'Sweet Banana' pepper. However, in many cases this is done at substantial expense to other growth parameters. The maximum DW of kale and lettuce was reached at lower fertilizer concentrations under subirrigation as compared with overhead watered plants, suggesting an increased fertilizer use efficiency in subirrigated plants. These two crops along with pepper also appeared to be sensitive to high fertilizer concentration under subirrigation but not under overhead irrigation. The fertilizer concentration required for maximum DW of collards and tomato was unaffected by irrigation method.

\section{Literature cited}

Bar-Tal, A., B. Bar-Yosef, and U. Kafkafi. 1990. Pepper transplant response to root volume and nutrition in the nursery. Agron. J. 82:989-995.

Biernbaum, J.A. and N.B. Versluys. 1998. Water management. HortTechnology 8:504-509.
Cantliffe, D.J. and P. Soundy. 2000. Vegetable transplant nutrient and water management. Acta Hort. 533:101-107.

Cavins, T.J., B.E. Whipker, W.C. Fonteno, B. Harden, I. McCall, and J.L. Gibson. 2000. Monitoring and Managing $\mathrm{pH}$ and EC Using the PourThru Extraction Method. North Carolina State Univ. Hort. Info. Lflt. 590. 9 Nov. 2011. <http://www. ces.ncsu.edu/depts/hort/floriculture/ hils/HIL590.pdfs.

Cox, D.A. 2001. Growth, nutrient content, and growth medium electrical conductivity of poinsettia irrigated by subirrigation or from overhead. J. Plant Nutr. 24:523-533.

Dole, J.M., J.C. Cole, and S.L. von Broembsen. 1994. Growth of poinsettias, nutrient leaching, and water-use efficiency respond to irrigation methods. HortScience 29:858-864.

Dufault, R.J. 1998. Vegetable transplant nutrition. HortTechnology 8:515-523.

Gibson, J., D.S. Pitchay, A.L. WilliamsRhodes, B.E. Whipker, P.V. Nelson, and J.M. Dole. 2007. Nutrient deficiencies in bedding plants: A pictorial guide for identification and correction. Ball Publishing, Batavia, IL.

Gladstone, L.A. and G.W. Moorman. 1989. Pythium root rot of seedling geraniums associated with various concentrations of nitrogen, phosphorus, and sodium chloride. Plant Dis. 73:733-736.

Haley, T.B. and D.W. Reed. 2004. Optimum potassium concentrations in recirculating subirrigation for selected greenhouse crops. HortScience 39:1441-1444.

James, E.C. and M.W. van Iersel. 2001 Fertilizer concentration affects growth and flowering of subirrigated petunias and begonias. HortScience 36:40-44.

Kang, J.G. and M.W. van Iersel. 2001. Interaction between temperature and fertilizer concentration affects growth and flowering of sub-irrigated petunias and begonias. J. Plant Nutr. 24:753-765.

Kang, J.G., M.W. van Iersel, and K.S. Nemali. 2004. Fertilizer concentration and irrigation method affect growth and fruiting of ornamental pepper. J. Plant Nutr. 27:867-884.

Konjoian, P. 1999. Vegetables, p. 110114. In: Tips on growing bedding plants, 4th ed. Ohio Florists' Assn., Columbus, $\mathrm{OH}$.

Mak, A.T.Y. and D.M. Yeh. 2001. Nitrogen nutrition of Spathiphyllum 'Sensation' grown in sphagnum peat- and coir-based media with two irrigation methods. HortScience 36:645-649.
Massa, D., N.S. Mattson, and J.H. Lieth. 2009. Effects of saline root environment $(\mathrm{NaCl})$ on nitrate and potassium uptake kinetics for rose plants: A MichaelisMenten modeling approach. Plant Soil 318:101-115.

Masson, J., N. Tremblay, and A. Gosselin. 1991. Nitrogen fertilization and HPS supplementary lighting influence vegetable transplant production. I. Transplant growth. J. Amer. Soc. Hort. Sci. 116: 594-598.

Nelson, P., C.Y. Song, and J.S. Huang. 2002. What really causes stretch? Greenhouse Product News 12(1):24-28.

Pinto, R.J., R.A. Chandler, and R.K. Dumroese. 2008. Growth, nitrogen use efficiency, and leachate comparison of subirrigated and overhead irrigated pale purple coneflower seedlings. HortScience 43:897-901.

Poole, R.T. and C.A. Conover. 1992. Fertilizers and medium affect foliage plant growth in an ebb and flow irrigation system. J. Environ. Hort. 10:81-86.

Richards, D.L. and D.W. Reed. 2004. New guinea impatiens growth response and nutrient release rate from controlledrelease fertilizer in a recirculating subirrigation and top-watering system. HortScience 39:280-286.

Rideout, J.W. and L.F. Overstreet. 2003. Phosphorus rate in combination with cultural practices reduces excessive growth of tomato seedlings in the float system. HortScience 38:524-528.

Schnelle, R. and J. Barrett. 2009. Sumagic and tomato transplants. Greenhouse Product News 19(11):20-23.

Todd, N.M. and D.W. Reed. 1998. Characterizing salinity limits of New Guinea impatiens in recirculating subirrigation. J. Amer. Soc. Hort. Sci. 123:156-160.

Tremblay, N. and M. Senecal. 1988. Nitrogen and potassium in nutrient solution influence seedling growth of four vegetable species. HortScience 23:1018-1020.

U.S. Department of Agriculture. 2009. Floriculture Crops 2008 Summary. 9 Nov. 2011. <http://usda01.library.cornell. edu/usda/nass/FlorCrop//2000s/ 2009/FlorCrop-04-23-2009.pdf>

Uva, W.L., T.C. Weiler, and R.A. Milligan. 1998. A survey on the planning and adoption of zero runoff subirrigation systems in greenhouse operations. HortScience 33:193-196.

Yelanich, M.V. and J.A. Biernbaum. 1993. Root-medium nutrient concentration and growth of poinsettia at three fertilizer concentrations and four leaching fractions. J. Amer. Soc. Hort. Sci. 118:771-776. 